\title{
Taking into Account the Corrections in the Study of the Properties of Substances by the X-ray Method
}

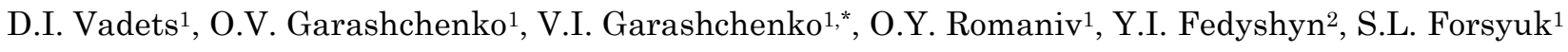 \\ 1 National University of Water and Environmental Engineering, 11, Soborna St., 33000 Rivne, Ukraine \\ 2 Stepan Gzhytskyi National University of Veterinary Medicine and Biotechnologies, 50, Pekars'ka St., \\ 79010 Lviv, Ukraine
}

(Received 12 June 2020; revised manuscript received 19 December 2020; published online 25 December 2020)

\begin{abstract}
The degree of influence of corrections was studied by the method of high-temperature radiography of alloys of $\mathrm{Cu}-\mathrm{Ni}, \mathrm{Fe}-\mathrm{Ni}, \mathrm{Au}-\mathrm{Ag}, \mathrm{KCl}-\mathrm{KBr}$ systems on the reverse imaging chamber on the diffuse temperature scattering of X-rays and scattering by defects of the crystal lattice. The research of the concentration and temperature dependences of the mean squares of the values of static and dynamic displacements of hypothetical atoms on their equilibrium positions in the crystal lattice was carried out. The method of separating the values of root-mean-square (RMS) dynamic and static displacements of atoms was described. The article is based on the choice of objects and research method. Mathematical relations for determining the temperature dependence of the X-ray characteristic temperature and complete RMS dynamic and static displacements of hypothetical atoms from the position of their equilibrium in the lattice are presented. The formulas for finding the values of the correction for temperature diffuse scattering of X-rays and the formula for calculating the values of static displacements are given through the parameter of the crystal lattice of the solid solution and the solvent, as well as through the values of the elastic constants of the investigated alloys. Some of the results of the investigation are illustrated graphically, and others - analytically. The advantage of the Chipman-Paskin method for determining the X-ray characteristic temperature and the advantage of evaluating the values of static displacements by temperature changes of the lattice parameter of the solid solution and the solvent are proved.
\end{abstract}

Keywords: RMS dynamic displacements, X-rays, Anharmonicity, Characteristic temperature, Alloys.

DOI: 10.21272/jnep.12(6).06019

PACS numbers: 61.66.Dk, 65.40.De

\section{INTRODUCTION}

When studying the thermal properties of substances and their alloys by the X-ray method, the question of the influence of X-ray scattering by crystal lattice defects is important. First of all, this concerns the values of the total medium quadratic dynamic $\overline{u_{d y n}^{2}}$ and static $\overline{u_{s t}^{2}}$ displacements of atoms from the equilibrium position in the crystal lattice and taking into account the corrections for thermal diffuse scattering (TDS) of X-rays and the manifestation of the anharmonicity of thermal vibrations of atoms.

This direction of experimental research was expanded by scientists from the Department of X-ray Metal Physics of Chernivtsi State University under the guidance of Professor G.P. Kushta. The method of determining the X-ray characteristic temperature $\Theta_{R}$ and its change was improved, and a generalized measure of anharmonic oscillations of the atoms of a crystalline substance was proposed. Such experimental researches are relevant today, as there are discussions about the feasibility of taking into account various amendments in determining the integral intensities of interference maxima of X-rays and the search for the optimal method of studying the thermal properties of substances.

\section{DESCRIPTION OF OBJECTS AND METHODS OF RESEARCH}

We investigated continuous solid solutions (alloys) of $\mathrm{Cu}-\mathrm{Ni}, \mathrm{Au}-\mathrm{Ag}, \mathrm{Fe}-\mathrm{Ni}$ and $\mathrm{KCl}-\mathrm{KBr}$ systems. A characteristic feature of $\mathrm{Cu}-\mathrm{Ni}$ and $\mathrm{Fe}-\mathrm{Ni}$ alloys is that the values of the atomic masses of their components are close to each other and are widely used in industry. Suffice it to remind the use of invar and permalloy alloys of the Fe-Ni group for memory cells.

$\mathrm{Au}-\mathrm{Ag}$ alloys are characterized by the fact that the filling of the upper electronic atomic shells is similar (Ag- $\left.4 d^{10} 5 s^{1}, \mathrm{Au}-5 d^{10} 6 s^{1}\right)$, although the atomic masses and radii are different. $\mathrm{Au}-\mathrm{Ag}$ alloys are corrosionresistant, often used in electronics.

The compounds $\mathrm{KCl}, \mathrm{KBr}$ and their alloys by structure belong to one class of ionic crystals of the $\mathrm{NaCl}$ type. They have found practical application in optics, in particular in the field of frequency overradiation associated with resonant oscillations of ions in the crystal lattice.

All research objects have a face-centered cubic (FCC) structure.

Researches of the above alloys were carried out by the method of high-temperature radiography using a KROS camera with a high-temperature nozzle to determine the temperature change of the parameter $a(t)$ of the crystal lattice and the change in the relative integral intensity of the interference line of a certain in$\operatorname{dex}(h k l)$. Based on them, the medium quadratic total $\overline{u_{t o t}^{2}}$ and static $\overline{u_{s t}^{2}}$ displacements of atoms from the position of their equilibrium in the crystal lattice were calculated.

The reasonable proposals of L.N. Guseva were accepted by us for determining the static displacements of alloy atoms by temperature and concentration change of the crystal lattice parameter

\footnotetext{
*v.i.harashchenko@nuwm.edu.ua
} 


$$
\overline{u_{s t}^{2}}=0,36 \frac{1-c}{c}\left[\frac{a_{m}\left(a_{p}-a_{m}\right)}{a_{p}}\right]^{2}
$$

where $c$ is the atomic concentration of impurities in the solid solution, $a_{p}$ and $a_{m}$ are the parameters of the crystal lattice of the solvent and the solid solution, respectively, at a given temperature.

The ratio of M.A. Kryvoglaz is also taken into account for alloys with FCC lattice:

$$
\overline{u_{s t}^{2}}=c(1-c) a^{2}\left(1+2 v_{1}\right)^{2}\left(\frac{1}{V} \frac{\partial V}{\partial c}\right)^{2} 10^{-2} \times\left[0,1424+\frac{1,204}{\left(1+v_{1}+2 v_{2}\right)^{2}}(1-1,055 \alpha)+2,47 \alpha^{2}-7,36 \alpha^{3}+24,2 \alpha^{4}+\frac{1,011}{1+v_{1}+2 v_{2}}\right]
$$

where $C_{i j}$ are the elastic constants; $V$ is the average atomic volume; $v_{1}=\frac{C_{12}}{C_{11}} ; v_{2}=\frac{C_{44}}{C_{11}} ; \alpha=\frac{v_{2}}{1+v_{1}+2 v_{2}}$.

Difficulties arise due to the limited amount of literature data on the concentration and temperature dependences of $C_{i j}$. Therefore, the degree of dependence $\overline{u_{s t}^{2}}$ on temperature and concentration of the solution can be estimated by relation (1).

When determining the dependence $\overline{u_{d y n}^{2}}(T)$ for alloys with FCC lattice, we took into account the amendments to the TDS [1]:

$$
\beta_{F C C}=\left(\frac{\pi}{3}\right)^{1 / 3} \frac{a \cdot \cos \vartheta \cdot \Delta \vartheta}{2 \lambda},
$$

where $a$ is the period of the crystal lattice, $\Delta \vartheta$ is the angular width of the photometric curve line $(h k l)$ of the order of $8-10^{\circ} ; \vartheta$ is the center of the Bragg angle of the interference maximum; $\lambda$ is the $\mathrm{X}$-ray wavelength.

Based on generally accepted considerations regarding the relative integral intensity of a certain interference maximum of X-rays, the equation can be written as

$$
I=B \cdot e^{-2 M(1-\beta)-L_{s t}},
$$

where $B$ is the product of the coefficient of proportiona- lity, angular and structural factors; $e^{-2 M}$ is the DebyeWaller temperature factor; $e^{-L_{s t}}$ is the weakening factor of the intensity of the interference maximum of $\mathrm{X}$ rays at static displacements of atoms from the equilibrium position; $\beta$ is the correction of TDS.

Exponents in the research of cubic syngony crystals can be expressed through dynamic $\overline{u_{d y n}^{2}}$ and static $\overline{u_{s t}^{2}}$ displacements of combined hypothetical atoms or through the characteristic temperature $\Theta_{R}$ :

$$
\begin{gathered}
2 M=\frac{4}{3} \pi^{2} \overline{u_{d y n}^{2}} \frac{\sum b_{i}^{2}}{a^{2}}=\frac{3 h^{2} T \psi(x) \sum b_{i}^{2}}{m k \theta^{2} a^{2}}, \\
L_{s t}=\frac{4}{3} \pi^{2} \overline{u_{s t}^{2}} \frac{\sum b_{i}^{2}}{a^{2}}
\end{gathered}
$$

where $h$ is the Planck constant; $k$ is the Boltzmann constant; $T$ is the thermodynamic temperature; $m$ is the total mass of hypothetical atoms of the crystal lattice; $\Sigma b_{i}{ }^{2}$ is the sum of the squares of crystal indexes $(h k l)$ of a certain interference maximum; $\psi(x)$ is a Debye function; $x=\Theta / T$.

By taking a crossgram or diffractogram at room and other temperatures, determining the relative intensities of a particular interference line and performing certain mathematical operations on (4), taking into account expressions (5) and (6), it can be written:

$$
\frac{1}{\Theta_{R}^{2}}=\frac{\left[\left(\ln \frac{B}{B_{0}}-\ln \frac{I}{I_{0}}\right)+\frac{4}{3} \pi^{2} \sum b_{i}^{2}\left(\overline{u_{0 s t}^{2}} \frac{\overline{u_{s t}^{2}}}{a_{0}^{2}}-\frac{a^{2}}{2}\right)\right] m k a^{2}}{3 h^{2} \sum b_{i}^{2}(1-\beta) T}+\frac{T_{0}\left(1-\beta_{0}\right)\left(1+\alpha \frac{\theta_{0}^{2}}{T_{0}^{2}}\right) a^{2}}{a_{0}^{2} \theta_{0}^{2} T(1-\beta)}-\frac{\alpha}{T^{2}},
$$

where index "0" refers to the values of physical quantities, for example, to room temperature, and without indices - to other temperatures. The coefficient $a$ can be found with a high degree of accuracy from the tabular values of the Debye function and a set of values $x=\Theta / T$ :

$$
\psi(x)=1+\alpha x^{2} .
$$

The feasibility of introducing the influence on the overall intensity of the interference maximum from the side of the TDS is not in doubt. Even at a constant value of $\Delta \vartheta, \beta$ increases with temperature due to an increase in $a(t)$, and the influence of static displacements should be evaluated by formula (1).

The temperature dependence $\Theta_{p}(T)$ was found by the known Chipman method [2]. For the most part, $\Theta_{p}(T)$ slowly decreases linearly with increasing temperature, $\overline{u_{d y n}^{2}}(T)$ or $\overline{u_{t o t}^{2}}(T)$ increases rapidly according to the quadratic law with increasing temper- ature of the test substance. Therefore, it is convenient to first determine the temperature dependence of the effective $\Theta_{R . e f f .}(T)$ by formula (7) without the term with $\overline{u_{s t}^{2}}$.

Having determined the effective values of $\Theta_{R \text {.eff. }}(T)$, we calculate the total values $\overline{u_{t o t}^{2}}(T)$ by the ratio:

$$
\overline{u_{t o t}^{2}}(T)=\frac{9 h^{2} T \psi(x)}{4 \pi^{2} m k \theta_{R . e f f}^{2}} .
$$

The mean square of the static displacement is determined by interrelation (1). Since the mean square of the total displacement is equal to

$$
\overline{u_{t o t}^{2}}=\overline{u_{d y n}^{2}}+\overline{u_{s t}^{2}},
$$

whence $\overline{u_{d y n}^{2}}=\overline{u_{t o t}^{2}}-\overline{u_{s t}^{2}}$.

If necessary, the actual values of X-ray temperatures $\Theta_{R}(T)$ can be calculated using (9). 


\section{DESCRIPTION AND ANALYSIS OF RESEARCH RESULTS}

Within the temperature researches of $\mathrm{Cu}-\mathrm{Ni}$ alloys up to $1073 \mathrm{~K}$, Fe-Ni up to $973 \mathrm{~K}$, Au-Ag up to $873 \mathrm{~K}, \mathrm{KCl}-\mathrm{KBr}$ up to $573 \mathrm{~K}$, we did not detect crystallographic structural changes.

The tables for the investigated alloys show the temperature changes of the total $\overline{u_{t o t}^{2}}(t), \overline{u_{s t}^{2}}(t), \overline{u_{d y n}^{2}}(t)$ displacements and the percentage contribution to $\overline{u_{s t}^{2}}$ in $\overline{u_{t o t}^{2}}$. Fig. 1, Fig. 2 show the concentration dependences $\overline{u_{s t}^{2}}(t)$ at different temperatures and their temperature change at different concentrations.

Table 1 - Concentration and temperature values of the RMS of the total, static and dynamic displacements of atoms and the fraction of static displacement relative to the total one as a percentage of $\mathrm{Au}-\mathrm{Ag}$ alloys

\begin{tabular}{|c|c|c|c|c|c|c|c|c|}
\hline \multicolumn{2}{|c|}{ Alloy, at. \%/temperature,${ }^{\circ} \mathrm{C}$} & $18^{\circ} \mathrm{C}$ & $100^{\circ} \mathrm{C}$ & $200^{\circ} \mathrm{C}$ & $300^{\circ} \mathrm{C}$ & $400{ }^{\circ} \mathrm{C}$ & $500{ }^{\circ} \mathrm{C}$ & $600^{\circ} \mathrm{C}$ \\
\hline \multirow{4}{*}{$\mathrm{Au}_{90}-\mathrm{Ag}_{10}$} & $1, \cdot 10^{-22}$ & 2.94 & 3.83 & 4.906 & 6.04 & 7.19 & 8.363 & 9.57 \\
\hline & $2, \cdot 10^{-22}$ & 0.000029 & 0.00032 & 0.0000032 & 0.0000032 & 0.000051 & 0.00015 & 0.000081 \\
\hline & $3, \cdot 10^{-22}$ & 2.94 & 3.83 & 4.906 & 6.04 & 7.19 & 8.363 & 9.57 \\
\hline & $4, \%$ & 0.0009 & 0.008 & 0.00006 & 0.00005 & 0.0007 & 0.0018 & 0.0008 \\
\hline \multirow{4}{*}{$\mathrm{Au}_{75}-\mathrm{Ag}_{25}$} & $1, \cdot 10^{-22}$ & 3.39 & 4.39 & 5.651 & 6.96 & 8.32 & 9.707 & 11.2 \\
\hline & $2, \cdot 10^{-22}$ & 0.000087 & 0.00013 & 0.00010 & 0.000017 & 0.00013 & 0.00021 & 0.00039 \\
\hline & $3, \cdot 10^{-22}$ & 3.39 & 4.39 & 5.651 & 6.96 & 8.32 & 9.706 & 11.2 \\
\hline & $4, \%$ & 0.002 & 0.001 & 0.0009 & 0.0009 & 0.001 & 0.001 & 0.003 \\
\hline \multirow{4}{*}{$\mathrm{Au}_{60}-\mathrm{Ag}_{40}$} & $1, \cdot 10^{-22}$ & 3.84 & 5.02 & 6.542 & 8.16 & 9.88 & 11.64 & 13.3 \\
\hline & $2, \cdot 10^{-22}$ & 0.000089 & 0.000091 & 0.00014 & 0.00014 & 0.00021 & 0.00036 & 0.00076 \\
\hline & $3, \cdot 10^{-22}$ & 3.84 & 5.02 & 6.542 & 8.16 & 9.88 & 11.63 & 13.3 \\
\hline & $4, \%$ & 0.002 & 0.001 & 0.002 & 0.001 & 0.002 & 0.009 & 0.005 \\
\hline \multirow{4}{*}{$\mathrm{Au}_{40}-\mathrm{Ag}_{60}$} & $1, \cdot 10^{-22}$ & 4.43 & 5.71 & 7.274 & 8.93 & 10.5 & 12.199 & 13.8 \\
\hline & $2, \cdot 10^{-22}$ & 0.00109 & 0.00114 & 0.00145 & 0.00157 & 0.00169 & 0.00174 & 0.0020 \\
\hline & $3, \cdot 10^{-22}$ & 4.43 & 5.71 & 7.273 & 8.92 & 10.5 & 12.197 & 13.8 \\
\hline & $4, \%$ & 0.02 & 0.01 & 0.02 & 0.01 & 0.01 & 0.01 & 0.01 \\
\hline \multirow{4}{*}{$\mathrm{Au}_{25}-\mathrm{Ag}_{75}$} & $1, \cdot 10^{-22}$ & 4.07 & 5.31 & 6.77 & 8.31 & 9.82 & 11.443 & 13.1 \\
\hline & $2, \cdot 10^{-22}$ & 0.00172 & 0.00148 & 0.00132 & 0.00125 & 0.00181 & 0.00181 & 0.00228 \\
\hline & $3, \cdot 10^{-22}$ & 4.07 & 5.31 & 6.769 & 8.31 & 9.81 & 11.441 & 13.1 \\
\hline & $4, \%$ & 0.04 & 0.02 & 0.01 & 0.03 & 0.01 & 0.01 & 0.01 \\
\hline \multirow{4}{*}{$\mathrm{Au}_{10}-\mathrm{Ag}_{90}$} & $1, \cdot 10^{-22}$ & 4.02 & 5.16 & 6.56 & 8.05 & 9.52 & 11.038 & 12.6 \\
\hline & $2, \cdot 10^{-22}$ & 0.000207 & 0 & 0.000051 & 0.000013 & 0.00020 & 0.00020 & 0.00046 \\
\hline & $3, \cdot 10^{-22}$ & 4.02 & 5.16 & 6.559 & 8.05 & 9.52 & 11.038 & 12.6 \\
\hline & $4, \%$ & 0.005 & 0 & 0.0007 & 0.0001 & 0.002 & 0.001 & 0.003 \\
\hline
\end{tabular}

Note: $1-\overline{u_{t o t}^{2}} ; 2-\overline{u_{s t}^{2}} ; 3-\overline{u_{d y n}^{2}} ; 4-\overline{u_{s t}^{2}} / \overline{u_{t o t}^{2}}$

Table 2 - Concentration and temperature values of the RMS of the total, static and dynamic displacements of atoms and the fraction of static displacement relative to the total one as a percentage of $\mathrm{Fe}-\mathrm{Ni}$ alloys

\begin{tabular}{|c|c|c|c|c|c|c|c|c|}
\hline \multicolumn{2}{|c|}{ Alloy, at. \%/temperature, ${ }^{\circ} \mathrm{C}$} & $20^{\circ} \mathrm{C}$ & $100^{\circ} \mathrm{C}$ & $200^{\circ} \mathrm{C}$ & $300^{\circ} \mathrm{C}$ & $400^{\circ} \mathrm{C}$ & $500^{\circ} \mathrm{C}$ & $700{ }^{\circ} \mathrm{C}$ \\
\hline \multirow{4}{*}{$\mathrm{Fe}_{65}-\mathrm{Ni} 35$} & $1, \cdot 10^{-22}$ & 1.629 & 2.09 & 2.71 & 3.49 & 4.11 & 4.93 & 6.64 \\
\hline & $2, \cdot 10^{-22}$ & 0.1 & 0.091 & 0.081 & 0.074 & 0.071 & 0.068 & 0.066 \\
\hline & $3, \cdot 10^{-22}$ & 1.528 & 2 & 2.63 & 3.416 & 4.04 & 4.86 & 6.58 \\
\hline & $4, \%$ & 6.17 & 4.36 & 3 & 2.13 & 1.73 & 1.39 & 1 \\
\hline \multirow{4}{*}{$\mathrm{Fe}_{56}-\mathrm{Ni}_{44}$} & $1, \cdot 10^{-22}$ & 1.227 & 1.54 & 1.95 & 2.376 & 2.8 & 3.29 & 4.36 \\
\hline & $2, \cdot 10^{-22}$ & 0.14 & 0.13 & 0.12 & 0.10 & 0.10 & 0.098 & 0.093 \\
\hline & $3, \cdot 10^{-22}$ & 1.086 & 1.41 & 1.82 & 2.267 & 2.7 & 3.19 & 4.26 \\
\hline & $4, \%$ & 11.47 & 8.65 & 6.32 & 4.61 & 3.67 & 3 & 2.14 \\
\hline \multirow{4}{*}{$\mathrm{Fe}_{50}-\mathrm{Ni}_{50}$} & $1, \cdot 10^{-22}$ & 1.223 & 1.57 & 2.03 & 2.585 & 3.11 & 3.67 & 4.93 \\
\hline & $2, \cdot 10^{-22}$ & 0.143 & 0.144 & 0.147 & 0.145 & 0.146 & 0.145 & 0.147 \\
\hline & $3, \cdot 10^{-22}$ & 1.08 & 1.43 & 1.88 & 2.44 & 2.97 & 3.53 & 4.78 \\
\hline & $4, \%$ & 11.7 & 9.17 & 7.24 & 5.61 & 4.69 & 3.95 & 2.98 \\
\hline \multirow{4}{*}{$\mathrm{Fe}_{30}-\mathrm{Ni}_{70}$} & $1, \cdot 10^{-22}$ & 1.322 & 1.71 & 2.26 & 3.031 & 3.66 & 4.46 & 6.53 \\
\hline & $2, \cdot 10^{-22}$ & 0.112 & 0.114 & 0.114 & 0.107 & 0.103 & 0.095 & 0.085 \\
\hline & $3, \cdot 10^{-22}$ & 1.21 & 1.6 & 2.15 & 2.923 & 3.56 & 4.36 & 6.44 \\
\hline & $4, \%$ & 8.49 & 6.63 & 5.04 & 3.56 & 2.81 & 2.14 & 1.3 \\
\hline \multirow{4}{*}{$\mathrm{Fe}_{20}-\mathrm{Ni}_{80}$} & $1, \cdot 10^{-22}$ & 1.205 & 1.56 & 2.05 & 2.51 & 3.35 & 3.9 & 6.23 \\
\hline & $2, \cdot 10^{-22}$ & 0.081 & 0.084 & 0.084 & 0.078 & 0.075 & 0.069 & 0.063 \\
\hline & $3, \cdot 10^{-22}$ & 1.123 & 1.48 & 1.96 & 2.432 & 3.28 & 3.83 & 6.17 \\
\hline & $4, \%$ & 6.8 & 5.42 & 4.1 & 3.1 & 2.24 & 1,79 & 1.01 \\
\hline
\end{tabular}




\begin{tabular}{|c|c|c|c|c|c|c|c|c|}
\hline \multirow{4}{*}{ Fe 10 -Ni90 } & $1, \cdot 10^{-22}$ & 1.199 & 1.63 & 2.14 & 2.75 & 3.53 & 4.39 & 6.7 \\
\cline { 2 - 10 } & $2, \cdot 10^{-22}$ & 0.032 & 0.036 & 0.04 & 0.0359 & 0.033 & 0.029 & 0.025 \\
\cline { 2 - 10 } & $3, \cdot 10^{-22}$ & 1.166 & 1.6 & 2.09 & 2.716 & 3.5 & 4.36 & 6.67 \\
\cline { 2 - 10 } & $4, \%$ & 2.71 & 2.24 & 1.88 & 1.3 & 0.94 & 0.67 & 0.37 \\
\hline
\end{tabular}

Note: $1-\overline{u_{t o t}^{2}} ; 2-\overline{u_{s t}^{2}} ; 3-\overline{u_{d y n}^{2}} ; 4-\overline{u_{s t}^{2}} / \overline{u_{t o t}^{2}}$

The investigated solid solutions behave differently, although there is a certain pattern between them. So, the concentration dependence $\overline{u_{s t}^{2}}(C)$ with both one and the other solvent increases with increasing concentration of impurities, reaching a maximum at 50 at. \% impurities in solid solutions.

For $\mathrm{Cu}-\mathrm{Ni}, \mathrm{Fe}-\mathrm{Ni}, \mathrm{Au}-\mathrm{Ag}$ alloys, the concentration dependence $\overline{u_{s t}^{2}}(C)$ at different temperatures is different. In particular, for solid solutions of $\mathrm{Cu}-\mathrm{Ni}$, this is due to similar temperature rapidity of the dependence $\overline{u_{s t}^{2}}(t)$.

Addition of $\mathrm{Ni}$ to the $\mathrm{Cu}$ solvent causes greater values of $\overline{u_{s t}^{2}}$ than addition of $\mathrm{Cu}$ to the $\mathrm{Ni}$ solvent. At room temperature, for alloys, for example, with 50 at. \% impurities, $\overline{u_{s t}^{2}}$ is $5 \%$ of $\overline{u_{t o t}^{2}}$, and up to $1.5 \%$ at high temperatures. Therefore, neither concentration nor temperature dependence $\overline{u_{s t}^{2}}$ should not be neglected.

For Fe-Ni alloys, the dependence $\overline{u_{s t}^{2}}(C)$ at different temperatures is obviously influenced by temperature changes of invar (35-45 at. \% Ni) and permalloy alloys, which is supported mainly by a decreasing temperature dependence $\overline{u_{s t}^{2}}(t)$.

For Fe-Ni alloys, at room temperature, the value of $\overline{u_{s t}^{2}}$ is $12 \%$ relative to $\overline{u_{t o t}^{2}}$ and $3 \%$ at high temperatures. Therefore, it is also undesirable to neglect the temperature dependence.

For Au-Ag alloys, the value of $\overline{u_{s t}^{2}}$ is 4-5 orders of magnitude less than $\overline{u_{t o t}^{2}}$. Therefore, the magnitude and temperature dependence of $\overline{u_{s t}^{2}}$ can be neglected, because their values are on the verge of accuracy of determination.

Concentration dependence $\overline{u_{s t}^{2}}(C)$ at different temperatures in solid solutions of $\mathrm{KCl}-\mathrm{KBr}$ is almost the same, which is due to the weak temperature change of $\overline{u_{s t}^{2}}(t)$. For $\mathrm{KCl}-\mathrm{KBr}$, for example, at 50 at.\%, $\overline{u_{s t}^{2}}$ is from $12 \%$ relative to $\overline{u_{t o t}^{2}}$ at room temperature to $5 \%$ at high temperatures. Therefore, the magnitude of $\overline{u_{s t}^{2}}$ cannot be neglected, and the temperature dependence is possible.

Calculations of $\overline{u_{s t}^{2}}$ at room temperature showed that their values found by formula (1) are 1.5 times greater than the values obtained by formula (2) for solid solutions of $\mathrm{Cu}-\mathrm{Ni}, \mathrm{Au}-\mathrm{Ag}, \mathrm{KCl}-\mathrm{KBr}$. Therefore, with separate determination of the mean squares of the dynamic and static displacements of hypothetical atoms from the equilibrium position, it is advisable to calculate the temperature change in the lattice parameter of the solid solution and solvent. The obtained data can be corrected by the elastic constants of the investigated alloys.

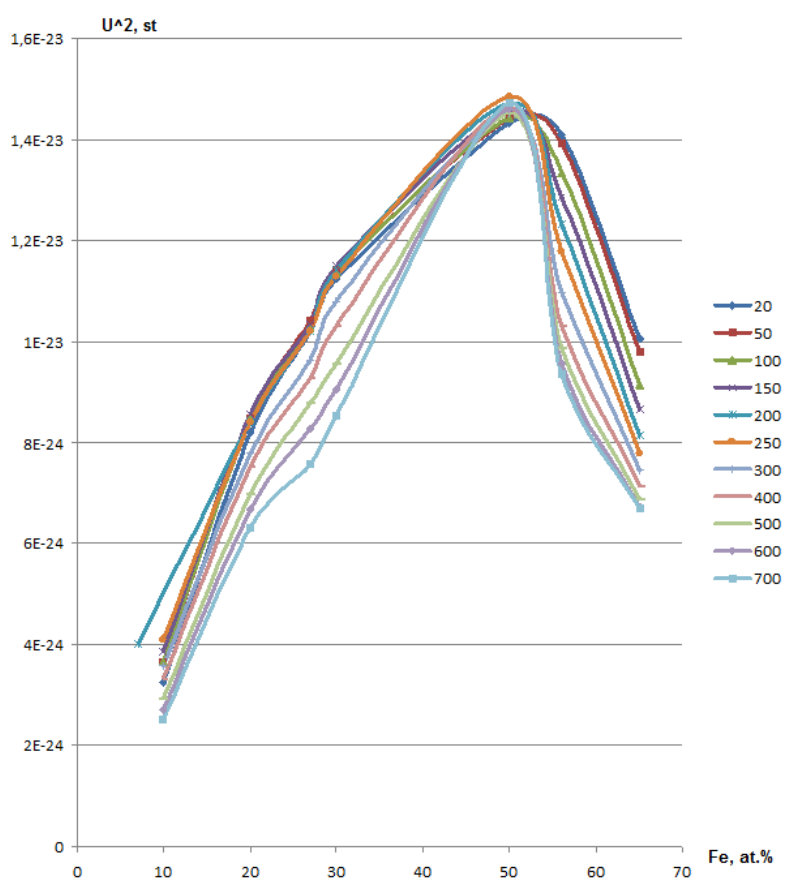

Fig. 1 - Concentration dependence of $\overline{u_{s t}^{2}}$ at different temperatures of $\mathrm{Fe}-\mathrm{Ni}$ alloys

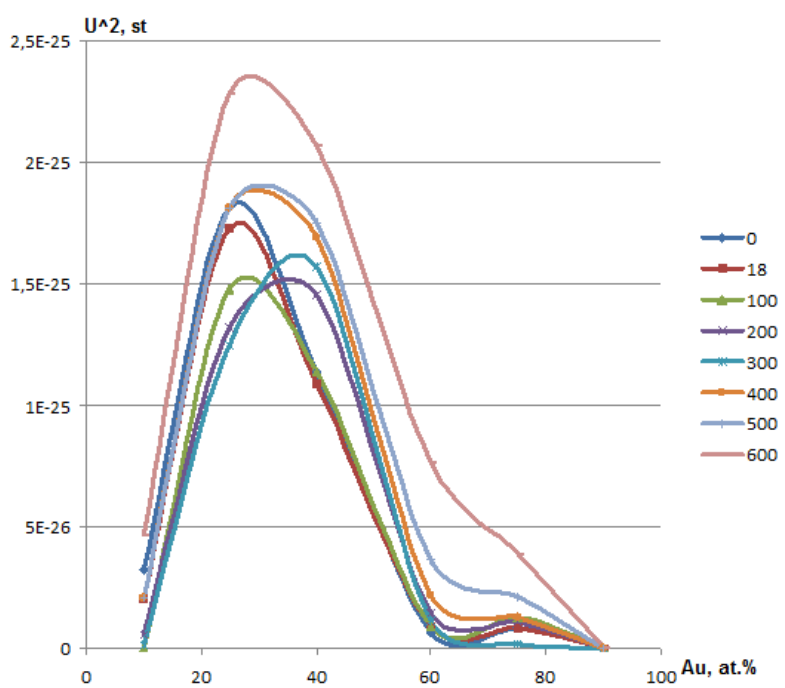

Fig. 2 - Concentration dependence of $\overline{u_{s t}^{2}}$ at different temperatures of $\mathrm{Au}-\mathrm{Ag}$ alloys

The research has also shown that the value of

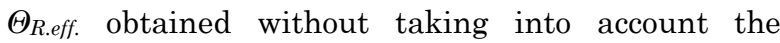
amendments to the TDS is greater than $\Theta_{\text {R.eff. re- }}$ 
ceived with amendments to $\beta$ which is about $4 \%$ at room temperature and $2 \%$ at high temperatures.

Similar results and the nature of the dependences were obtained by V.A. Valchykovska in the research of other solid solutions.

\section{CONCLUSIONS}

No crystal structural changes were detected in the investigated temperature range.

With separate determination of the mean squares of the dynamic and static displacements of hypothetical atoms of the crystal lattice from the position of their equilibrium, it is expedient to calculate the value of $\overline{u_{s t}^{2}}$ by the temperature change in the crystal lattice parameter of the solid solution and solvent. The received data can be corrected by the elastic constants of the searched alloys. It turned out that the values of $\overline{u_{s t}^{2}}$, calculated from the parameters of the crystal lattice at room temperature, are 1.5 times greater than $\overline{u_{s t}^{2}}$ calculated from the elastic constants of solid solutions.

\section{REFERENCES}

1. D.R. Chipman, A. Paskin, J. Appl. Phys. 30, 1998 (1959).
With increasing concentration of impurities in alloys $\overline{u_{s t}^{2}}$ increases, and its temperature change in different solid solutions and in size and nature is different.

Therefore, it is always necessary to estimate size and character of change in the static displacement and make a decision on the expediency of taking into account the correction for $\overline{u_{s t}^{2}}$.

The temperature change of the effective X-ray characteristic temperature $\Theta_{R \text {.eff. without correction }}$ for TDS of X-rays for test substances is higher by $4 \%$ at room temperature and $2 \%$ at high temperatures

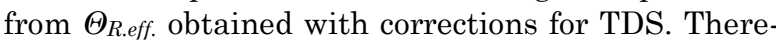
fore, they should be taken into account, and in the presence of the values of $\overline{u_{s t}^{2}}$ and $\overline{u_{t o t}^{2}}$ one can get a clearer description of the manifestation of the anharmonicity of thermal oscillations $\overline{u_{d y n}^{2}}(t)$. In our opinion, the most optimal way to determine the dependence of the X-ray characteristic temperature is Chipman-Paskin method by analyzing the family of curves $\Theta_{R}(T)$.

\title{
Врахування поправок при дослідженні властивостей речовин рентгенівським методом
}

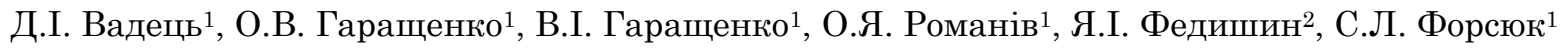 \\ ${ }^{1}$ Національний університет водного господарства та природокористування, вул. Соборна, 11, \\ 33000 Рівне, Україна \\ 2 Львівський національний університет ветеринарной медицини та біотехнологій імені С. Іжицького, \\ вул. Пекарська, 50, 790010 Львів, Україна
}

\begin{abstract}
Методом високотемпературного рентгенографування сплавів систем $\mathrm{Cu}-\mathrm{Ni}, \mathrm{Fe}-\mathrm{Ni}, \mathrm{Au}-\mathrm{Ag}, \mathrm{KCl}-\mathrm{KBr}$ на камері оберненого знімання проведено дослідження ступеню впливу поправок на температурне дифузне розсіювання рентгенівських променів та розсіювання дефектами кристалічної гратки. Проведено дослідження концентраційної і температурної залежностей середніх квадратів значень статичних та динамічних зміщень гіпотетичних атомів від їх положень рівноваги у кристалічній гратці. Описана методика розділення значень повних середньоквадратичних динамічних і статичних зміщень атомів. В статті обгрунтований вибір об’ектів і методу дослідження. Наведені математичні співвідношення з визначення температурної залежності рентгенівської характеристичної температури, повного середньоквадратичного динамічного та статичного зміщень гіпотетичних атомів від положення їх рівноваги в гратщі. Наведені формули для знаходження значень поправки на температурне дифузне розсіювання рентгенівських променів, формули обчислення значень статичних зміщень через параметр кристалічної гратки твердого розчину та розчинника, а також через значення пружних постійних досліджуваних сплавів. Частина результатів дослідження проілюстрована графічно, а інша - аналітично. Доведена перевага методу Чіпмена-Паскіна 3 визначення рентгенівської характеристичної температури та перевага оцінки значень статичних зміщень за температурними змінами параметра гратки твердого розчину і розчинника.
\end{abstract}

Ключові слова: Середньоквадратичні динамічні зміщення, Рентгенівські промені, Ангармонізм, Характеристична температура, Сплави. 